\title{
Conversa desarmada: teoria, crítica e literatura
}

\author{
Bruno Pucci* \\ Christian Muleka Mwewa**
}

\begin{abstract}
Resumo
A partir da ideia de Romance de formação, o presente texto traz um diálogo entre os autores Bruno Pucci e Christian M. Mwewa. O debate está alicerçado na Teoria Crítica e Literatura. A "conversa" gira em torno de três romances, quais sejam: Um rio chamado tempo, uma casa chamada terra; Un amour de Swann; Grande Sertão: veredas. O texto inicia como um 'diálogo' para tomar a forma de 'debate' e por fim transforma-se em uma 'conversa'. Estes três níveis 'diálogo, debate, conversa', de alguma forma, buscam reafirmar a dialetica presente nos romances.
\end{abstract}

Palavras-chave

Teoria Crítica. Formação. Literatura.

\section{Notas sobre Romance de formação}

Mazzari (2006, p. 7-8), na apresentação do livro Os anos de aprendizado de Wilhelm Meister, afirma que Goethe "empreendeu a primeira grande tentativa de retratar e discutir a sociedade de seu tempo de maneira global, colocando no centro do romance a questão da formação do indivíduo, do desenvolvimento de suas potencialidades sob condições históricas concretas". Segundo Lukács (2006), esta amplitude não constava na versão anterior do mesmo livro: "a nova versão amplia-se, portanto, para uma representação de toda a sociedade" (2006, p. 582). É sob estas condições que se inaugura o gênero que mais tarde será denominado como Romance de formação por Karl Morgenstern em 1819, afirma Mazzari.

Willi Bolle (2004), no capítulo em que analisa a "representação do povo e invenção da linguagem", compreende que Grande sertão: veredas "é o romance de formação do Brasil, ideia que [...] consolida [no livro grandesertão.br] através de uma

\footnotetext{
* Docente da Universidade Metodista de Piracicaba, UNIMEP, Brasil. Doutor em Educação: História, Política, Sociedade pela Pontifícia Universidade Católica de São Paulo.

** Docente do programa de Pós-Graduação em Educação da Universidade do Sul de Santa Catarina. Doutor em Ciências da Educação pela Universidade Federal de Santa Catarina (UNISUL). E-mail: christian.mwewa@unisul.br.
} 
reflexão sobre o romance de formação enquanto romance social" (2004, p. 375). Como se pode ver, o autor não toma as duas dimensões de forma separada. É importante perceber que ele, Bolle, não se atém à separação entre esses dois tipos de abordagem na sua análise do livro de Guimarães Rosa. O termo "romance de formação" (Bildungsroman) foi criado por Karl Morgenstern em 1819 e difundido por Wilhelm Dilthey $(1870,1906)$, cujo protótipo é Wilhelm Meister (1795-96) de Goethe. Neste "projeto arrojado", segundo Bolle, "a idéia de que a pessoa se forma num campo de energias sociais e políticas é sustentada estrategicamente pela figura do narrador, que realiza um complexo trabalho de mediação entre os diferentes discursos sociais" (BOLLE, 2004, p. 382). Portanto, Willi Bolle (2004, p. 378) indica que, conforme Benjamin, o romance de formação "se define pelo conflito entre as leis da sociedade e a aspiração do indivíduo à autonomia". Ou seja:

...a idéia de formação, intensamente discutida no meio intelectual e artístico alemão por volta de $1789-1795$, não se limitava, de modo algum, à dimensão do indivíduo, mas se estendia explicitamente ao "povo" e à "humanidade" como um todo (Herder), com desdobramentos numa teoria da linguagem e da literatura de abertura universal (Goethe). (BOLLE, 2004, p. 382).

No Brasil, a palavra "Formação", "utilizada já por Euclides da Cunha e, como título de obra, pela primeira vez, por João Pandiá Calógeras, em Formação histórica do Brasil (1930), [...] tornou-se a partir de então uma 'verdadeira obsessão' entre os retratistas do país" (BOLLE, 2004, p. 383-84). Pode-se dizer que, de forma indireta, esta já era uma preocupação dos romancistas antes de escreverem os seus romances. Ao elaborar verdadeiros trabalhos arqueológicos, em termos benjaminianos, Machado de Assis indicava o local onde se encontrara a "ossatura" em que se constituiu a sociedade brasileira. Com base no "raio $x$ " machadiano, ainda podemos verificar na contemporaneidade os sinais das estruturas sociais por ele escavadas.

Roberto Schwarz (2000a), no seu clássico Ao vencedor as batatas, cuja primeira edição data de 1977, faz um estudo detalhado sobre "a formação literária e [o] processo social nos inícios do romance brasileiro". Na mesma direção de análise da formação literária brasileira, o autor escreve Um mestre na periferia do capitalismo, Machado de Assis (2000b), editado pela primeira vez em 1990. Num estudo comparativo, Schwarz localiza, na obra de José de Alencar e na de Machado de Assis, mais detidamente, o retrato da constituição e formação social do Brasil. Em relação aos primeiros romances Machadianos, Schwarz afirmar que "onde Alencar alinhara pelo realismo, pelas questões do individualismo e do dinheiro [...], Machado se filiava à estreiteza apologética da Reação européia, de fundo católico, e insistia na santidade das famílias e na dignidade da pessoa (por oposição ao seu dinheiro)" (2000a, p. 83). Schwarz localiza o partenalismo e a sua racionalização nos primeiros romances de Machado de Assis, como por exemplo, em "A mão e a luva (cinismo ingênuo); Helena (purismo); Iaiá Garcia (desencanto)". 


\section{Teoria, Crítica e Literatura}

Bruno Pucci: Sobre "a formação na constelação das mediações culturais" retomo a observação de que a temática é instigante e desafiadora. Parte da necessidade de atualização da compreensão do conceito de cultura, tal como conceituada por Adorno ${ }^{1}$. Busca, nas entrelinhas do próprio pensador frankfurtiano e no diálogo com Canclini e Stuart Hall, outros elementos para fazê-lo. É uma tese contra Adorno a partir de Adorno. Este, sobretudo, em seus ensaios da Teoria Estética, da Dialética Negativa e das Notas de Literatura; Canclini na reivindicação da necessidade de um adentramento das culturas marginalizadas no mercado global; e Hall no postulado do território da marginalidade como um lócus privilegiado da fala e da reação; dão ao pesquisador elementos teóricos e metodológicos para avançar em sua proposta. Após abordar as contribuições dos três pensadores (o primeiro lídimo representante da cultura erudita; os outros dois que buscam status para as culturas dos países periféricos), Christian examina a temática em três provocantes romances na tentativa de comprovar (iluminar ainda mais) sua hipótese de trabalho. No primeiro, de Proust, a formação de Swann reflete objetivamente a perspectiva da cultura erudita, ocidental na tensão com a cultura do senso comum de seu contexto; em Mia Couto, a tensão entre as culturas erudita e a do povo de uma ilha africana; e, em Rosa, a presença da cultura do sertão dos Geraes no monodiálogo com o doutor da cidade.

Christian Muleka: Não por isso que devemos considerar os autores de forma estanque, ou seja, Adorno enclausurado como pensador da cultura erudita; Canclini defensor do direito de as culturas populares gozarem das benesses da indústria cultural; e Hall como aquele que vê na marginalidade a opção da fala como o lugar imposto aos subalternizados. É verdade que em suas anotações, juntamente com Max Horkheimer em relação à indústria cultural, Adorno centra-se na possibilidade de compreender criticamente o mecanismo que ofusca a autonomia do sujeito. Nesse aspecto, torna possível abranger outros elementos fundamentais para repensarmos a questão da cultura. No contexto de ofuscamento que a indústria cultural realiza, os produtos - inclusive a cultura - são fabricados em escala industrial a partir de pressupostos socioculturais que primam pelo consumo em diferentes âmbitos. Esta suposição, no entanto, não encontra necessariamente ressonância direta em seus destinatários. Ou seja, não há nenhuma lei ou controle que nos obrigue a reagir ao produto da forma como seus mentores o planificaram. Talvez esteja indicada aí uma possibilidade de romper algumas amarras, presentes na relação cultural, internalizadas no sujeito. No que se refere à arte, Adorno valoriza o dissonante, o ininteligível, o indizível, ao tomar como referência a música, mais especificamente a de Schoenberg. Desta forma, o autor diz existir naquele que não se adapta facilmente uma

${ }^{1}$ Esta conversa está referenciada na arguição feita por Bruno Pucci na ocasião da defesa da tese: MWEWA, Muleka. Adorno, Hall e Canclini: a Formação na constelação das mediações culturais. (Tese de Doutorado). Centro de Ciências da Educação. Universidade Federal de Santa Catarina, Florianópolis, 2010. 
possibilidade de ruptura com a linearidade da cultura dominante. Dominante, aqui, refere-se à cultura que é genericamente consumida por todos em diferentes âmbitos e escalas. E não somente à cultura consumida por aqueles que "dominam", isto é, que possuem meios para o seu consumo. Pois, hoje, qualquer pessoa pode canta-en-rolar a quinta sinfonia de Beethoven. Basta apenas "baixá-la" da rede mundial de computadores (Internet) diretamente para o seu celular. Ou ainda citar Baudelaire nas conversas de bar, a partir de edições resumidas de suas obras. A questão não está na recusa de acesso à população, mas sim na promiscuidade com que tais obras são tratadas quando chegam a esses âmbitos. Já, no que se refere a outros contextos culturais, Adorno, geralmente, é acusado de uma dupla "desatenção", qual seja: 1) ao analisar o Jazz, por exemplo, Adorno não se aprofundou em conhecer as condições contextuais dos negros, ou seja, aquelas específicas da produção cultural do outro, que se materializam fora do eurocentrismo, exceto dos trabalhos realizados nos Estados Unidos da América; e 2) quando as conheceu, comparou-as de forma partidária às produzidas na Europa. A partir desta observação, reafirmamos a necessidade de considerar outros elementos na sua ideia de cultura para que esta não sucumba sob as críticas que a consideram elitista. Por outro lado, a simples vitimização daqueles que não são considerados como sendo da "elite" tampouco nos ajuda a equalizar, na contemporaneidade, a perspectiva cultural adorniana. Quem domina a técnica da percussão oriunda de países africanos, por exemplo, pode ser percebido como pertencente a uma certa "elite"? A dúvida é: como ficariam as críticas de elitista direcionadas a Adorno se esta técnica fosse apreciada pelas camadas média e alta da sociedade? Temos inúmeras manifestações de culturas consideradas marginalizadas que ascenderam ao rol das atividades destas camadas sociais, como a Capoeira e o Samba, por exemplo. Essa ascensão embaralha, de certa forma, o discurso idílico dos seus agentes. Quando Adorno se refere ao jazz como música negra, tem em mente a música considerada erudita, música pela qual Adorno tinha tão imensa devoção a ponto de se afirmar como alguém que pensava com os ouvidos. A princípio, podemos dizer que este autor dominava de forma impar um contexto musical, mas não o do Jazz, porque este era concebido a partir de outras bases culturais, não apenas as de consumo como atesta em sua crítica. Estas, por sua vez, diferenciavam-se das bases culturais da música erudita. Por outro lado, o próprio Adorno, indica nos seus escritos a importância de se considerar o contexto.

Bruno Pucci: A estrutura do trabalho ${ }^{2}$ está bem posta: é coerente, tensiona com equilíbrio os aspectos teórico-metodológicos com os exemplos empíricos de análise. O trabalho está adequadamente formulado, bem escrito e articulado de maneira expressiva e didática. Minhas observações [em relação a este aspecto] visam apenas a melhoria do texto. Parto, à semelhança de Christian, da constatação de que o conceito de Indústria Cultural, criado no contexto do capitalismo tardio dos anos 1940 do século passado, em pleno contato de seus autores com a cultura americana desse período (a mais avançada no momento em termos de civilização ocidental) continua sendo atual e frutuoso na interpretação dos fenômenos culturais dos dias de

\footnotetext{
${ }^{2}$ Refere-se à tese. Ver nota 88.
} 
hoje [2010], e que, também, a partir de seus críticos e de seus analistas, foi ganhando novas configurações no confronto com os desafios e problemas colocados pelo desenvolvimento histórico contemporâneo. Nesse contexto, as contribuições de Canclini e de Hall, não obstante algumas de suas teses questionáveis/difíceis de serem sustentadas ${ }^{3}$, ajudam-nos a entender melhor os conceitos de cultura e de indústria cultural a partir dos olhares não centrais do sistema. Concordo também com Christian na observação de que esses críticos de Adorno não possuem um conhecimento maior do conjunto dos escritos culturais de Adorno. Além de que, como dizia o frankfurtiano, em seu texto "ensaio como forma", "Ele (o ensaio) não começa com Adão e Eva, mas com aquilo sobre o que deseja falar; diz o que a respeito Ihe ocorre e termina onde sente ter chegado ao fim, não onde nada mais resta a dizer". Ou seja, o ensaio não tem intenção nenhuma de esgotar o sentido do objeto. E Adorno, quase sempre se expressava através de ensaios. E ainda mais, nesse mesmo texto, à p. 30, Adorno indica a maneira como o contexto sócio-cultural tem que ser levado em consideração para se entender suas expressões.

Christian Muleka: Ainda que busquemos uma valorização das culturas ditas próprias ou originais, colocamo-nos à mercê do selo daqueles que compram (consomem). Portanto, a quem devemos criticar, quando não nos sentimos contemplados pela valorização cultural na forma como esta foi posta? $\mathrm{E}$, contra o quê devemos estar preparados? A aparente impossibilidade dos países periféricos de possuírem condições mais adequadas para uma estabilidade social, política e econômica beira a incapacidade destes de se legitimarem como detentores de culturas que dialogam de forma equânime com a integração global a que todos aspiram. Essa incapacidade pode ser verificada na corrida aos financiamentos dos organismos internacionais, que incentivam o aumento das importações em detrimento do aproveitamento interno (não necessariamente nesta ordem) dos produtos (incluindose os culturais) desses países periféricos. Para tanto "[...] es necesario distinguir en qué sentido la nueva articulación entre mercancías y significados contribuye al desarrollo, de distinto modo en los países centrales y periféricos" (CANCLINI, 2002, p. 60). Um dos caminhos apontados por este autor é conceber a cultura como expressão paradoxal de um lugar que possibilita o exercício de certa subjetividade e, ao mesmo tempo, a sua crítica, a exemplo de Diadorim em Grande Sertão: veredas de Rosa. Desta maneira, advogamos em direção à necessidade desta operação dar-se de forma dialética, quer dizer, a da liberdade adquirida culturalmente poder reformular as práticas sociais intermediadas pelo sujeito. Sabemos, porém, que não é exatamente assim que a liberdade se dá, vale observar, de forma consecutiva à operação de adição, ou seja, cultura mais sociedade é igual à valorização social por aqueles que não podem aceder ao universo social culturalmente seletivo. Essa adição só é possível porque parte de um equívoco prévio, que concebe a cultura à parte da dinâmica social como um todo e a subdivide em categorias seletivas. A classificação, neste caso, serve

3 Canclini: "é necessário um adentramento das culturas marginalizadas no mercado global, com espaço de ação específica, para que elas façam frente ao solapamento cultural realizado pelos países hegemônicos". Hall: "o território da marginalidade seja um local privilegiado da fala por ele ainda não estar imediatamente submetido à indústria cultural". 
como critério de exclusão. Podemos tomar a categorização da arte em popular e erudita (esta aparente polarização é aqui tomada na forma de estratégia metodológica) para exemplificar estas classificações. Muitas vezes as compreendemos de forma excludente, mas, no entanto, se integram em alguma medida de forma perversa na indústria cultural. Esta produção da arte em escala industrial pressupõe uma diluição das particularidades do objeto artístico num coletivo. Este processo é obscurecido para o funcionamento dos mecanismos próprios que constituem a lógica da indústria cultural. Tal dimensão se encontra presente tanto na chamada cultura popular quanto na referida cultura erudita. Os elementos dos quais a arte (cultura) se vale para realizar a crítica social imanente da sua pertinência social podem ser concebidos como possíveis pistas para a compreensão das dinâmicas da arte na sua face formativa apontadas por Adorno. Essa face pode ser tomada no seu caráter de crítica utópica na e da sociedade capitalista (EAGLETON, 2005). É nesta direção que encaminhamos a assertiva de Stuart Hall com a qual corrobora, em certa medida, Nestor Garcia Canclini, qual seja: de tempos em tempos, apresenta-se uma nova necessidade de se configurar o social de forma diferente. Canclini localiza na indústria cultural uma possibilidade de integração entre os países centrais e periféricos, motivo pelo qual este autor é questionado pelo professor Bruno. Crítica com a qual concordo. No entanto, esta integração ainda se realiza por meio de uma globalização concebida de forma unilateral pelos países centrais. Os países periféricos se colocam à mercê dos centrais, apesar de encontrarem meios que os mantenham na relação, a marginalidade, por exemplo, à qual se refere Hall, se a pensarmos enquanto o outro do centro. Adorno coloca a necessidade de uma crítica cultural imanente da sociedade nesta integração social por via do conceito de indústria cultural. Este conceito não pode ser tomado como panacéia da democracia do consumo, pois, este é objetivado no seu caráter perverso (de dominação) na indústria da cultura quando funcionaliza (coloca em prática) as relações sociais mediadas pela cultura. A autocrítica da cultura, neste caso, torna-se uma dimensão fundamental para impulsionar o sujeito a estabelecer uma relação de não-identidade com os aparatos culturais que tendem a inibi-lo. É preciso refletir, por exemplo, acerca da cultura em Theodor W. Adorno, a partir de elementos centrais presentes em alguns textos da obra do referido autor frente à sua noção de cultura, como enunciado pelo professor Bruno Pucci no início desta conversa. Seu texto, de Adorno, sobre a Teoria Estética, por exemplo, de uma maneira geral, traz importantes indicações sobre a compreensão que Adorno tem da cultura. A configuração desta cultura, como observa o autor, também não está alheia às determinações implementadas pela e na indústria cultural. Não é uma posição submissa que esta ocupa, porém se converte em arauto das mazelas sociais neste contexto. De fato, na contemporaneidade, possuir noções básicas de uma cultura erudita fortalece a expectativa de pertencimento a grupos sociais diferenciados ou "supervalorizados". Aqui, por exemplo, já pulula em nós a questão: valorizado por quem? Os grupos diferenciados podem determinar o subproduto cultural a ser classificado como popular numa relação de "inocente" superioridade, que não é aparente. O popular torna-se subproduto na medida em que delega sua valorização às camadas sociais consideradas superiores. 
Bruno Pucci: Retomo uma das propostas de Canclini, de difícil aceitação, qual seja, "é necessário um adentramento das culturas marginalizadas no mercado global, com espaço de ação específica, para que elas façam frente ao solapamento cultural realizado pelos países hegemônicos". Christian, comentando a expressão de Canclini, diz: "Não sabemos o quanto é útil o modelo trasnacional para pensar as produções culturais dos países periféricos, pois, em outras palavras, estamos dizendo aos países centrais que não temos outra forma de difundir nossa cultura a não ser pelos meios que eles protagonizam". E traz o exemplo da "exportação da capoeira". Gostaria de apenas fazer duas observações: 1. Adorno, ao retomar nos anos 1960, o conceito de Indústria cultural, ressalta sua ambiguidade, tanto no termo cultura quanto no termo indústria. A dimensão da ambiguidade na cultura é clara igualmente nos textos "Teoria da Semiformação", "Sobre a música popular" e em seus escritos educacionais. Então, embora predomine em suas análises os efeitos nocivos da Indústria Cultural, em nenhum momento ele afirma seu domínio absoluto. Há, pois, a possibilidade de algum produto cultural da periferia invadir os países centrais do mundo globalizado e, quem sabe, gerar espaços/momentos de crítica, de resistência, de emancipação. Porém, a desproporção entre o poder do sistema, da indústria cultural, da semiformação e o poder das intervenções dos países periféricos é tão grande que as possibilidades de mudanças são exíguas. No entanto, Adorno continua afirmando: "[...] estamos sob o domínio do anacronismo: agarrar-se com firmeza à formação depois que a sociedade já a privou de base. Contudo, a única possibilidade de sobrevivência que resta à cultura é a auto-reflexão crítica sobre a semiformação, em que necessariamente se converteu". Christian, à p. 74, faz uma afirmação forte e, a meu ver, frágil sobre os frankfurtianos, quando diz: "Nem tudo aquilo que é promovido pelas indústrias culturais deve ser considerado nocivo, como em certa medida afirmam os frankfurtianos".

Christian Muleka: Antes de tudo, é importante afirmar que Adorno é um autor que dispensa ser defendido, pela magnitude de sua obra e pela exepcional abrangência dos temas por ele tratados. $E$, principalmente, pela atualidade das suas análises. Por isso mesmo, é passível de ter ignorado nelas algum caráter ao qual outros se apegam. Ou seja, Adorno sabe se defender sozinho, mas também não escreveu palavras bíblicas. Para Adorno, a mesma indústria cultural de que os produtores da cultura popular reclamam, e a que promove artistas desconhecidos que progridem rapidamente nas suas carreiras, iguala-se na objetivação do lucro. Neste sentido, ela anularia as possibilidades de um sujeito autônomo. A controvérsia é que, se não fosse pela arquitetura da indústria cultural, o Museu do Dundo, em Angola, por exemplo, nunca iria expor obras do angolano José Redinha ${ }^{4}$. A importância social que esta exposição teve para seus compatriotas ou artistas que se encontram na mesma situação escapa aos franfurtianos. Aliás, eles mesmos põem em causa o alto controle da indústria cultural quando o telespectador não reage à piada do protagonista do filme como os "promotores" previam. Ou seja, quando o destinatário não tem a reação prevista, pode falhar o mecanismo de controle. Quantas propagandas nos levaram a

\footnotetext{
${ }^{4}$ A respeito desta exposição ver Patrícia Ferraz de Matos (2008).
} 
repudiar um produto ao invés de adotá-lo? Que eles, os promotores, saberão aproveitar (no sentido de lucrar) deste fato, todos sabemos, pois são sempre "eles" (representando um coletivo onipresente) que lucram e não "nós" representantes do coletivo vitimizado. Mas pode não ser possível acreditar que o repúdio estava previsto pelos seus mentores. Por outro lado, pensar naquilo que nos leva a reivindicar algo nesta nova configuração do social é importante para não exigirmos, por exemplo, o direito a participar da indústria cultural, como proclama Canclini. Devemos considerar, aí sim, os mecanismos ou os partidos aos quais ela, a indústria, está vinculada. Nem tudo aquilo que é promovido pelas indústrias culturais pode ser considerado nocivo. Sabemos do processo de democratização da cultura promovido por ela, quando tomado enquanto substância, assim argumentam seus "advogados". Porém, indústria cultural deve ser compreendida como movimento e conceito que ajuda a compreender uma realidade. Mas ela, também, divulga a sua outra face, qual seja, a sujeição dos seus consumidores. A pronúncia do pronome "nós" obscurece euforicamente a pretendida "... atualização [da tese] do ópio do povo", como diria Hall (2003). Na indústria, o indivíduo é ilusório não apenas por causa da padronização do modo de produção. Ele só é tolerado na medida em que sua identidade incondicional com o universal está fora de questão. Da improvisação padronizada em jazz até os tipos originais do cinema, que têm de deixar a franja cair sobre os olhos para serem reconhecidos como tais, o que domina é a pseudo-individualidade. $O$ individual reduzse à capacidade do universal de marcar tão integralmente o contingente que ele possa ser conservado como o mesmo. "[...] As particularidades do eu são mercadorias monopolizadas e socialmente condicionadas, que se fazem passar por algo de natural." (HORKHEIMER; ADORNO, 1985, p. 144-145). Concordamos, assim, com Hall, em relação ao "[...] número substancial de trabalhadores que está incluído na recepção dos produtos da indústria cultural" (HALL, 2003, p. 253), pois eles, enquanto indivíduos trabalhadores, passam a ser seus primeiros destinatários duplamente privilegiados. Primeiro, porque trabalham e podem se endividar ou pagar em suaves (relativo ao suor) prestações pelos produtos adquiridos; segundo, porque o fato de serem trabalhadores leva-os a requerer atividades diversas do trabalho diário. Portanto, parece-me, professor Bruno, que esta outra face passa despercebida para Jonhson e Canclini. Um, pelo enaltecimento de um coletivo previamente fabricado, sem considerá-lo altamente manipulável; outro, por almejar, na indústria cultural, uma instância integradora livre do solapamento das liberdades individuais e coletivas como contrapartida. Faço esta afirmação justamente para reforçar o meu ponto de vista do caráter prioritariamente nocivo da indústria cultural. Quando este caráter não é contemplado em primeiro plano, o seu subproduto, a positivação da indústria cultural, é cooptado logo em seguida. Como vê, professor, neste ponto, seguimos discordando. Realmente, existe um coletivo que é louvado na indústria cultural, assim como o mesmo é nela fabricado; sim, existe uma instância integradora na indústria cultural, mas esta integração não é feita sem custos. A indústria cultural comporta internamente este paradoxo de forma desequilibrada. Sempre com prejuízo para um dos lados. O problema pode estar nos seus estudiosos, que não suportam a ambivalência de alguns conceitos, pois esta ambivalência os obriga a estar sempre atento para não empregar os conceitos no "atacado", castrando-os ou asfixiando-os. 
Bruno Pucci: Bem, voltando à sua tese no item 3.1 "Swann e a formação objetiva" você trabalha a partir do livro de Proust o percurso formativo do qual Swann se valeu para estabelecer suas relações no contexto em que convivia com Odette, em especial. Porém, um outro aspecto, esse importantíssimo, que mereceria ser tratado no texto (na sua tese) e que envolve o livro de Proust enquanto um todo é a questão da memória involuntária. Essa categoria (ou realidade) permeia as descrições e análises de Proust e, portanto, a formação objetiva e as manifestações culturais de Swann. A questão que lhe coloco é a seguinte: não seria a memória involuntária a forma primordial da vida e da narrativa da paixão de Swann por Odette? Veja bem: durante boa parte do relacionamento de Swann com Odette, ele não a achava bonita e nem mantinha relações sexuais com ela; ele saia sim com a "operariazinha rechonchuda" e muitas vezes chegava atrasado ao clã dos Verdurin. Foi somente quando ele percebeu, por acaso, a semelhança de Odette com a imagem de Zéfora, a filha de Jetro, pintada por Botticelli, é que ele começou a se apaixonar por ela; à medida que Swann se imerge no clã dos Verdurins, se deixa levar pelo senso comum, pela semiformação, como você diz bem. As poucas vezes em que ele se enleva, vai além do senso comum, é pela memória involuntária; ou seja, ao ouvir aquela pequena frase musical que fazia parte da Sonata para Piano e Violino, de Vinteuil (e no livro ele vai ouvi-la pelo menos em dois momentos especiais; tocada pelo pianista no clã dos Verdurins e, mais ao final do livro, na visita que faz à marquesa de Saint-Euverte), Swann viaja através do tempo e do espaço. E essa frase musical marca o seu relacionamento com Odette e expressa instantes significativos deste. Na casa dos Verdurins a frase musical vai caracterizar momentos de felicidades ao lado de Odette; na última audição, em casa da marquesa de Saint-Euverte, a audição, que novamente o enleva, vai demarcar tristeza, sofrimento, pois seu relacionamento com Odette está muito ruim. E, para colocar outro aspecto fundamental, é a memória involuntária que vai ser decisiva na "imersão" de Swann, na sua separação definitiva de Odette. É depois de um sonho, em que Swann revê mais uma vez Odette, mas ela the surge não com a semelhança da filha de Jetro, de Botticelli, e sim como das primeiras vezes em que Swann a tinha visto e não a achava bonita. E, após ser acordado por seu criado, essa lembrança da Odette primeira Ihe vêm à memória e ele toma sua decisão.

Christian Muleka: Concordo com você, professor, pois, essa observação já foi feita na ocasião do exame de qualificação da referida tese. Mas, esta questão não era central para mim, pela sua complexidade, por isso reafirmo: No caso de Swann, faz-se importante, de forma marginal, localizar o conceito de memoire involontaire. Marginal, porque entendemos a extrema importância desta categoria em Proust, mas nossas análises se concentram, em especial, na formação objetiva e em como Swann se relaciona com manifestações culturais (com as obras de arte) e com o amor que alimenta por Odette de Crecy (MWEWA, 2010, p. 121). Agora me permita fazer apenas algumas observações: é por meio de uma memória, que é acionada pelo acaso, que toma o sujeito de assalto, o sujeito é transportado para algum momento significativo da sua vida, cujo tempo, em que se "viaja", é vivido com o inocente desprendimento 
feliz, sem deixar, porém, de ter sérias implicações para o espírito que reconhece os seus limites. Em Proust, nesta viagem, sur place, o sujeito se apropria daquilo que é próprio do narrador: a possibilidade de narrar. Mas, desta vez, este viaja no tempo intrasubjetivo para recolher substâncias a serem trazidas à luz do espírito para que sejam "narradas" ao próprio espírito. Ou seja, para que o espírito tome consciência de forma a se apropriar desta experiência trazida dos lugares mais recônditos de sua memória. Mais uma vez, vislumbra-se, neste processo, o procedimento de materialização da obra de arte, isto é, a tradução da ideia em material possível de ser apreendido por outros sujeitos. Isto é flagrante mesmo na impossibilidade de apreensão do objeto desejado pelo protagonista, a Odette, depois de reconhecer a semelhança desta com a filha de Jetro, de Botticelli.

Bruno Pucci: No item em que você discute sobre Diadorim "Reinaldo" e a dialética do sujeito na relação há uma ressalva que gostaria de fazer. No encontro do menino Riobaldo com o menino Reinaldo, no De Janeiro, que desemboca no São Francisco; nessa ocasião, Riobaldo vivia com sua mãe, Bigri, muito pobremente. Depois da morte da mãe, ele vai morar com seu padrinho/pai, seu Selorico, amigo e hospedeiro dos jagunços em sua fazenda; aprende a ler e a escrever. Foge da casa paterna e vai trabalhar de professor numa escola, por recomendação do mestre, seu Lucas. Torna-se professor de um dos maiores jagunços da época, Zé Bebelo. Foge do lugar, vagueando pelo sertão e, ao pedir pouso em uma fazenda, encontra os jagunços de Joca Ramiro, e, entre eles, Reinaldo (Diadorim), agora jagunço. Na época, Hermógenes era o lugar-tenente de Joca Ramiro. Tempos depois acontece a prisão de Zé Bebelo e o seu julgamento: o famoso júri do sertão. Riobaldo é seu defensor e Hermógenes, acusador. Zé Bebelo é absolvido e libertado. Hermógenes, indignado, à traição, assassina Joca Ramiro, pai de Reinaldo. Ai, sim, toda a vida/perspectiva de Reinaldo, já irmanado com Riobaldo, que se torna chefe dos jagunços, é vingar a morte do pai. Há uma questão de fundo no romance: porque Diadorina aparece sempre vestida de homem? O encontro entre os dois meninos no De Janeiro nos mostra que Reinaldo não apenas se formou objetivamente nas tensões de seu cotidiano como mulher/homem; mas também se formou educando o outro, Riobaldo ("Carece de ter coragem. Carece de ter muita coragem"). Ele ensina a Riobaldo uma dupla lição: que não se deve temer as forças da natureza (a travessia dos rios); e nem a força dos homens (sua reação rápida e certeira contra o rapaz que o queria molestar sexualmente). Rosa, nessa parte, já apresenta, pelo menos em dois episódios, essa "figura ambígua, dúplice e dissimulada", que é Diadorim (episódio do rapaz que o ataca sexualmente; Reinaldo pegando nas mãos de Riobaldo e este se sentindo "vergonhoso, perturbado". Ainda, no livro, Riobaldo aprende com Reinaldo a fruir da contemplação das flores e dos pássaros, além de valorizar a sensibilidade, a amizade, a ponderação no contexto violento da jagunçagem. A glosa da canção de Siruiz, uma canção estranha do cantador Siruiz, que ecoa no meio da madrugada, anuncia acontecimentos futuros da vida de Riobaldo e, ao mesmo tempo, incita o herói a lançar-se à sua aventura. Aí então, "um falou mais alto, aquilo era bonito e sem tino: - Siruiz, cadê a moça virgem?"... Algum, aquele Siruiz, cantou, palavras diversas, 
para mim a toada toda estranha" (GSV5 , p. 93). A glosa da canção de Siruiz está no meio do Grande Sertão: veredas, em um longo parágrafo (p. 235-237), que se inicia com a descrição da Vila Urubú. E, segundo o próprio Rosa, "... nesse longo parágrafo, mais ou menos no meio do livro, o que temos é uma exposição, entrecruzada, de todos os motivos principais [...]. Riobaldo não entende bem o que está por trás daqueles versos, mas desconfia que em suas desdobras algo está velado, algo se esconde: "A vida é muito discordada. Tem partes, tem artes. Tem as neblinas de Siruiz. Tem as caras todas do cão e as vertentes do viver" (GSV, p. 381). Do mesmo modo, Diadorim se apresenta a ele como encoberto por neblinas, que o impedem de ver: "Em Diadorim penso também - mas Diadorim é a minha neblina" (GSV, p. 22). Em Diadorim, a moça virgem esconde-se sob a forma de um jagunço. Em suma, a canção de Siruiz, tal como a esfinge, afrontou o herói em sua lida pelo sertão. A rememoração dela, de forma enigmática, possibilitava-Ihe advinhações benfazejas e decisivas em sua travessia. E mostra como Diadorim se forma objetivamente no contexto do texto e como ele é sempre uma figura complementar e formadora de Riobaldo. E vice-versa. Nesta intersecção do encontro entre Reinaldo e Riobaldo o autor, Guimarães Rosa, fortalece a relação permanente dos personagens. Para tanto, se valeu da língua enquanto um importante recurso. Na expressão de Canclini, "estudiar La cultura requiere, entonces, convertirse em um especialista de las intersecciones". Guimarães Rosa trabalhou com profundidade e intensidade as "intersecciones" da língua dos sertanejos na cultural nacional e internacional, seja no refinamento da expressividade das palavras existentes, seja na criação de novas palavras para expressar melhor uma ideia ou realidade, seja na seriedade com que dialogava com seus tradutores na busca do termo mais consonante. Vou trazer apenas um exemplo de suas "intersecciones": A explicação a seu tradutor italiano do sentido do adjetivo "grimo", utilizado no conto "Recado do Morro", atribuído a "um homenzinho terém-terém, ponderadinho no andar, todo arcaico", chamado Gorgulho: "um velhote grimo". Foi ele que ouviu e repassou o recado do morro. Explica Rosa: "Grimo": de uma feiúra sério-cômica, parecendo com as figuras dos velhos livros de estórias; feio carateante; de rosto engelhado, rugoso. (Cf. em italiano: grimoso = Vecchio grinzoso). Em inglês: grim = carrancudo, severo, feio, horrendo, sombrio etc. Em alemão: Grimm = furioso, sanhoso. Em dinamarquês: grimme $=$ feio. $\mathrm{Em}$ português: grima = raiva, ódio; grimaça = careta". E termina assim sua orientação: "Eu quis captar o quid, universal, desse radical" (2003, p. 69). Em relação a busca da expressão (linguagem) que mais se aproxima daquilo que está contido na ideia, vale lembrar que Guimarães Rosa, foi acusado por inúmeros militantes, políticos e/ou escritores, de não ter tomado posição explícita contra o governo militar. E a resposta de G. Rosa se dá através de seus escritos. Dizia ele a seu tradutor inglês: "Não procuro uma linguagem transparente. Ao contrário, o leitor tem de ser chocado, despertado de sua inércia mental, da preguiça e dos hábitos. Tem de tomar consciência viva do escrito, a todo momento. Tem quase de aprender novas maneiras de sentir e de pensar. Não o disciplinado - mas a força elementar, selvagem. Não a clareza - mas a poesia, a obscuridade do mistério, que é o mundo. E é nos detalhes,

\footnotetext{
${ }^{5}$ Grande Sertão: Veredas.
} 
aparentemente sem importância, que estes efeitos se obtêm. A maneira-de-dizer tem de funcionar, a mais, por si".

Christian Muleka: Neste ponto, professor, eu só tenho a agradecer a belíssima aula que acaba de nos dar sobre Guimarães Rosa e seus escritos. Mas, permita-me algumas palavras sobre a questão da formação a partir de Diadorim. Para efeitos de análise, e do ponto de vista do gênero, pode-se dizer que ela (Diadorim) era uma mulher, porém mulher que se igualava aos homens externamente, empreendendo um outro tipo de sexualidade ${ }^{6}$. Aquela sexualidade que podia gozar de toda a proximidade corporal com o outro, coisa não muito comum para os jagunços, a não ser em situação de luta corporal; que podia exteriorizar seus sentimentos, pois Riobaldo sabia que "Diadorim tinha ciúme" (ROSA, 1984, p. 179), mas, também, tinha que abrir mão da sua realização total. Diadorim, portanto, configura-se como o não-idêntico por se diferenciar dos outros na expressão do dissonante na paisagem do Sertão. Ela contraria a realidade em relação ao gênero, que atesta sua existência como que num processo de instauração do novo na quebra da normalidade compartilhada. Claro está que a leitura acima só é possível depois que sabemos de sua condição de mulher, pois enquanto homem, na situação romanesca extremamente complexa, ele/ela podia ser visto como um transgressor das regras do Sertão ao expressar seu ciúme por um homem, por exemplo. Portanto, é sabido que Maria Deodorina da Fé Betancourt Marins só vive depois de morta, pois em vida ela era Reinaldo, um "homem". Apesar de ser "concebido" no e pelo contexto do Sertão, ela difere dos demais a partir de algumas atitudes efeminadas em determinados momentos com Riobaldo. Estas atitudes, em parte, vão de encontro àquelas pressupostas pelo contexto geral e, no entanto, só podiam ser notadas pela pessoa com quem mantinha uma relação direta, ou seja, Riobaldo. Este, não sem razão, é o narrador "participante", que tudo sabe e para quem "contar é muito dificultoso. Não pelos anos que se já passaram. Mas pela astúcia que têm certas coisas passadas - de fazer balancê, de se remexerem dos lugares." (ROSA, 1984 , p. 172). Há, naquelas atitudes de Diadorim, certa dose de racionalização das mesmas frente à necessidade de sobrevivência que o Sertão demanda. Se fosse permitido, explicitamente, a outros jagunços perceberem-na, sua permanência corria risco naquele contexto. Os jagunços podem ser igualados uns aos outros, apesar de cada sujeito ter as suas idiossincrasias, mas em resumo: são homens em situação de luta e em vida. Poder igualar-se traz, como sua extensão, a possibilidade de poder ser substituído. Se pensarmos no Grande Sertão: veredas enquanto um romance de formação, pode-se dizer que numa sociedade, na qual a uniformidade é incentivada o processo de dominação ou de produção das mercadorias específicas, demanda-se do sujeito certa irracionalidade, isto é, espera-se que ele seja adaptável sem ter os fins programados. É possível dizer, junto com Adorno (2007, p. 56), que se engendra um contexto social "[...] que viu a possibilidade de substituir qualquer um a qualquer coisa

\footnotetext{
${ }^{6}$ É importante lembrar que no romance só ela se sabia mulher fato este que veio a tona, para Riobaldo, em especial, somente no momento da morte de Diadorim/Reinaldo. Como é sabido, ao longo de todo o romance Riobaldo se relaciona com o "homem": Reinaldo.
} 
que, [o contexto] conserva um toque de irracionalidade " mas que, em última análise, deve ser racionalizado. Assim, diz Riobaldo, lamentando a perda de Diadorim:

E, o podre de mim, minha tristeza me atrasava, consumido. Eu não tinha competência de querer viver, tão acabadiço até o cumprimento de respirar me sacava. $\mathrm{E}$, Diadorim, às vezes conheci que a saudade dele não me desse repouso; nem o nele imaginar. [...] Para quê eu ia conseguir viver? Mas, o amor de minha Otacília também se aumentava, aos berços primeiro, esboço de devagar. Era. (ROSA, 1984, p. 565).

Os limites de compreender a realidade da forma como ela se apresenta não podem significar uma empreitada em direção a sua facilitação ou a sua descomplexificação (se permitido nos for o termo), para que esta não seja produto da falta de consciência, como querem os promotores da sociedade administrada. Portanto, se coloca aí, perante a não facilitação da compreensão da realidade de forma simplória, uma necessidade de perceber o contexto no qual Diadorim viveu como homem (o masculino social e culturalmente construído), pois esse contexto se apresenta num progressivo movimento de render justiça ao Sertão heterossexualmente sustentado pelo imaginário comum. Só assim se podem perceber os mecanismos do funcionamento arquitetados no contexto, longe de simplesmente torná-los perceptíveis, mas sim manejáveis. Diadorim busca sempre uma forma de estabelecer uma interação, na qual a aparente obediência torna-se uma forma de mostrar as lacunas do outro na relação, na medida em que só se descobre o seu gênero (feminino) no momento de sua morte. Ele/ela era apenas Ela, circunscrevendo, assim, o momento da verdade em sua existência. Em termos adornianos, se pensarmos na morte de Diadorim ou mesmo em sua objetividade ao cumprir sua missão, pode-se dizer que ela se negou a aceitar as coisas como mera existência. Por meio desta atitude, foi possível, para ela, vislumbrar uma vida para além das possibilidades postas pelo contexto. Por outro lado, não é seguro afirmar que ela teria as mesmas possibilidades, caso viesse a "comunicar" (neste caso falar) sua condição feminina: "falei sonhando: - 'Diadorim, você não tem, não terá alguma irmã, Diadorim?'", diz Riobaldo numa das cenas mais sensuais do romance (ROSA, 1984, p. 170). Como se enfrentaria este tipo de questionamento caso se soubesse de antemão de sua condição de mulher, revelada para Riobaldo somente depois da morte.

\section{Referências}

ADORNO, Theodor Wiesegrund. Dialectique négative. Paris: Payot, 2007.

BOLLE, Willi. Grandesertão.br: o romance de formação do Brasil. São Paulo: Livraria Duas Cidades: Editora 34, 2004.

CANCLINI, Nestor Garcia. Latinoamericanos buscando lugar en este siglo. Buenos Aires: Paidós, 2002.

\footnotetext{
7 « qui a vu la possibilité de substituer n'importe qui à n'importe qui, [le contexte] conserve un touche d'irrationalité. » Tradução nossa.
} 
EAGLETON, Terry. A idéia de cultura. São Paulo: Editora UNESP, 2005.

HALL, Stuart. Da diáspora: identidades e mediações culturais. Liv Sovik (Org.); Trad. de Adelaine la Guardia Resende et alii. Belo Horizonte: Ed. UFMG; Brasília: Representações da UNESCO no Brasil, 2003.

HORKHEIMER, Max e ADORNO, Theodor W. Dialética do esclarecimento: fragmentos filosóficos. Rio de Janeiro: Zahar, 1985.

LUKÁCS, Georg. Posfácio In: GOETHE, J. W. Os anos de aprendizado de Wilhelm Meister. Tradução de Nicolino Simone Neto; apresentação Marcus V. Mazzari - São Paulo: Ed. 34, 2006.

MATOS, Patrícia F. Projectos colonias e seus efeitos: o caso do trabalho de José Redinha desenvolvido no Museu do Dundo. In: MWEWA, Muleka. (Org.). África e suas diásporas: olhares interdisciplinares. São Leopoldo: Nova Harmonia, 2008. p. 57-86.

MAZZARI, Marcus V. Apresentação. In: GOETHE, J. W. Os anos de aprendizado de Wilhelm Meister. Trad. de Nicolino Simone Neto; apresentação Marcus V. Mazzari; posfácio de Georg Lukács. São Paulo: Ed. 34, 2006. 608p.

ROSA, João Guimarães. Grande sertão: veredas. 16 ed. - Rio de Janeiro, 1984.

ROSA, J. G. Correspondência com seu tradutor italiano Edoardo Bizzarri. 3. edição. Rio de Janeiro, Nova Fronteira, 2003.

SCHWARZ, Roberto. Ao vencedor as batatas: forma literária e processo social nos inícios do romance brasileiro. 5. ed. São Paulo: Duas Cidades; Ed. 34, 2000a.

. Um mestre na periferia do capitalismo: Machado de Assis. 4. Ed. São Paulo:

Duas Cidades; Ed. 34, 2000b.

\section{Title}

Disarmed Conversation: Theory, Criticism and Literature

\section{Abstract}

The present paper presents a dialogue between authors Bruno Pucci and Christian M. Mwewa around the idea of the Bildungsroman. Such a debate is grounded on Critical Theory and Literature. The 'conversation'occurs around three novels, Um rio chamado tempo, uma casa chamada terra; Un amour de Swann; Grande Sertão: veredas. The discussion begins with a 'dialogue' that is reshaped as a 'debate', till finally becoming a 'conversation.' These three levels, 'dialogue, debate, conversation,' aim at reaffirming the dialectics present in the novels.

\section{Keywords}

Critical Theory. Formation. Literature.

Recebido em 22.08.2011. Aprovado em 09.11.2011. 